\title{
RAFAє MAŃKO
}

University of Amsterdam

\section{THE COOPERATIVE MEMBER'S PROPRIETARY RIGHT TO AN APARTMENT: A LEGAL SURVIVAL OF THE PERIOD OF ACTUALLY EXISTING SOCIALISM IN POLISH PRIVATE LAW}

\section{INTRODUCTION}

Following a transformation from one socio-economic and political system to another, such as that from "actually existing socialism" to a democratic market economy, the legal system usually undergoes a likewise profound modification. Whilst this fact is undoubtedly the rule, it is not without exceptions. Those exceptions are legal institutions which "survive" the demise of the earlier socio-economic and political system and endure under new, changed circumstances. In this paper, I will refer to such institutions as "legal survivals", consciously drawing upon the notion of a "survival" developed in sociology and anthropology, later to be transplanted to the sociology of law ${ }^{2}$.

1 In this article I understand the notion of "actually existing socialism" (otherwise known as "really existing socialism", "real socialism" or "state socialism") as referring to the political, social and economic system prevailing in the Soviet Union and other countries of the former Soviet bloc. The element of "actually existing" in the term serves to emphasise the gap between "socialism" in the strict sense of the word (as envisaged, e.g. by Marx and Engels or by non-Soviet Marxists) and the actual economic, political and social practice in the Soviet bloc. When describing a country under "actually existing socialism", I will use the adjective "state socialist".

2 See e.g. B. Malinowski, A Scientific Theory of Culture and Other Essays, New York 1961 [1944], p. 29; M. WeBer, Economy and Society: An Outline of Interpretive 
The cooperative member's proprietary (in rem) right to an apartment in a housing cooperative is an example of a such a legal survival - it emerged in the 1950s, when Poland was a state-socialist country within the Soviet bloc, in order to serve the specific agenda of that period, namely a compromise between the requirement that preference be given to so-called 'socialised' property (such as cooperative property) and the need of providing persons who finance the construction of their apartment from their own resources with a sufficiently attractive legal title. After the transition to a market economy in 1989, the original raison d'être of this right disappeared. In spite of that, proprietary rights to apartments in newly constructed housing stock could still be established until 2007 and in existing housing stock, under certain conditions, until the end of 2012. The paper aims at exploring the reasons of the existence of this legal survival in the modified socio-economic environment, thus shedding some light on the adaptation of a formerly socialist legal system to the requirements of a market economy after 1989 in the Central European post-transformation context.

As regards methodology, the present paper combines a historical, dogmatic and socio-legal approach. It presents the historical evolution of a legal institution - in casu the proprietary right to a cooperative apartment - in its political and socio-economic context. The focus is not so much on the Dogmengeschichte of this institution, as on its changing socio-economic function and the modifications of its legal form which enabled such a change.

This is in light of the purpose of the paper, which is twofold. First of all, it aims at presenting the evolution of the legal framework of the

Sociology, Berkeley-Los Angeles 1978, p. 25, 69-71. Probably the first legal scholar who analysed survivals in law in a systematic way was the Austrian sociologist of law Karl Renner, who devoted an entire monograph to the topic (K. Renner, The Institutions of Private Law and Their Social Functions, translated by A. SCHWARZSCHILD, London 1976 [1904]. For a comperehensive presentation of the theory of legal survivals see R. Mańко, Relikty w kulturze prawnej. Uwagi metodologiczne na tle pozostałości epoki socjalizmu realnego w polskim prawie prywatnym, «Przegląd Prawa i Administracji» 52/2015; Idem, Legal Survivals: A Conceptual Tool for Analysing Post-Transformation Continuity of Legal Culture, [in:] Tiesību efektivitāte postmodernā sabiedrībā [Effectivness of Law in Post-Modern Society], ed. J. RozenfeldS ET AL., Riga 2015. 
cooperative member's proprietary right to an apartment with a particular emphasis on its modifications after 1989. Secondly, it aims at presenting the historical evolution of that legal institution as a "legal survival" of the period of actually existing socialism, emphasising the change of its social function as a necessary prerequisite of its endurance. The right is presented in its socio-legal and ideological context, hence sections on the privileged role of "social" property (section 2.1), on the role of housing cooperatives (section 2.2) and their legal framework in socialist Poland (2.3.1), and on the impact of Poland's transformation upon its housing policy (section 3.1).

The general ordering of the paper's sections is chronological. Hence, section 2 is devoted to the socialist period, and section 3 to the post-socialist period. The conclusions (section 4) aim at analysing the change of the social function of the cooperative member's proprietary right to an apartment and the importance of this change for the endurance of this right in the Polish legal order qua legal survival of the socialist period.

2. THE COOPERATIVE MEMBER'S PROPRIETARY RIGHT TO AN APARTMENT UNDER ACTUALLY EXISTING SOCIALISM

\subsection{Privileged Role of "SOCIAL" property}

A fundamental tenet of the legal system of actually existing socialism was the privileged role of "social" property, as opposed to personal property (of items for personal use) and individual property (used for economic activity by private parties) ${ }^{3}$. Social property was subdivided into two types: national (state) property and group property. State property was treated as the most perfect form of social property because (in

\footnotetext{
3 K. Zweigert, H. KöTz, Introduction to Comparative Law ${ }^{2}$, I: The Framework, Oxford 1987, p. 335ff.; W.E. Butler, Soviet law, London 1983, p. 169-70. The privileged position of state property consisted, inter alia, in its immunity from usucapio (acquisition of property by a third party as a result of long-term de facto possession) and from attachment in civil enforcement proceedings, severe limits on its alienation and a higher level of protection under the rules of criminal law.
} 
theory) it belonged to the entire society ${ }^{4}$. Group property, encompassing property held by cooperatives and by other organisations (social organisations, trade unions, political parties) was treated as an inferior form of social property because it did not belong to the entire society but only to a certain group of that society ${ }^{5}$. Nevertheless, although being an inferior form of social property (as compared to state property), cooperative property enjoyed an ideological preference in the system of actually existing socialism over private property. The privileged position of socialised property was not merely a question of terminology or sheer conceptual jurisprudence, but had a real impact upon the level of protection afforded by the law ${ }^{6}$. In particular, Articles 199-202 of the Criminal Code of 1969 provided for a special regime of protection of social property, distinct from the regime of protection of private property, and Article 4 of Code of Civil Procedure of 1964 contained a special rule implementing the protection of socialised property within civil proceedings ${ }^{7}$.

\subsection{ROLE OF HOUSING COOPERATIVES}

Directly after World War II, when Poland underwent a transition to actually existing socialism, initially it was the state itself which acted as the main investor in the housing sector ${ }^{8}$. The role of existing coop-

4 J. Wasilkowski, Prawo własności w PRL. Zarys wykładu [Right of Ownership in the Polish People's Republic: Outline of a Lecture], Warszawa 1969, p. 27.

5 J. Wasilkowski, op. cit., p. 55.

6 R. МАŃко, 'We Do Not Recognise Anything "Private": Public Interest and Private Law Under the Socialist Legal Tradition and Beyond, [in:] Private Interest and Public Interest in European Legal Tradition, ed. B. SiteK ET AL., Olsztyn 2015, p. 39.

7 Article 4 k.p.c. in its original wording of 1964: 'The court shall be under a duty to afford appropriate protection of social property. In particular, the court shall inform the superior body of an entity of the socialised economy which is party or participant of the proceedings if persons appointed to represent that entity are not active in the proceedings, do not observe the binding provisions or do not follow the court's orders or if it may be appropriate to entertain procedural actions with regard to persons not participating in the proceedings. If necessary, the court shall inform a prosecutor.'

8 A. Andrzejewski, Zarys polityki mieszkaniowej [An Outline of Housing Policy], Warszawa 1979, p. 102ff, 201. 
eratives in the construction of new dwellings gradually shrank ${ }^{9}$. They became practically "deprived of any possibilities of development and of influence upon their housing stock"10, eventually leading to their elimination from the housing sector in Poland.

During the early 1950s, the main area of state investment was (heavy) industry at the expense of consumption, including housing ${ }^{11}$, This translated itself into a growing housing deficit which became a major social problem, with just one newly built dwelling per four newly established families ${ }^{12}$. Furthermore, tenants in state-owned apartment buildings, who paid highly subsidised rents, did not present due care for the state of the housing facilities, which led to their fast deterioration ${ }^{13}$. The government's decision to give a new role to cooperatives in the development of the national housing stock was motivated by various factors. First of all, it allowed for the transferring of resources from the fund of consumption (salaries and personal savings, enterprise funds) to finance housing investment, hitherto financed entirely and directly by the state's local administration ${ }^{14}$. Secondly, it was believed that citizens who have financed their own apartment by way of long-term savings and further payment of instalments would demonstrate more responsibility and care for the housing facilities offered to them ${ }^{15}$. This political choice required an adequate legal solution which would allow combining ultimate state control over the housing stock with a legal form which, nevertheless, would still seem sufficiently attractive to persuade citizens to allocate their own resources. The choice not to grant citizens, who fully financed the construction of their apartment, a right of ownership over the apartment, was

9 T. Kowalak, Dorobek spółdzielczości w trzydziestoleciu Polski Ludowej [The Output of the Cooperative Sector during the Three Decades of People's Poland], Warszawa 1975, p. 103-104.

10 K. MAdEJ, Spółdzielczość mieszkaniowa. Władze PRL wobec niezależnej inicjatywy spółdzielczej [Housing Cooperatives: The Authorities of the Polish People’s Republic Towards Independent Cooperative Initiative], Warszawa 2003, p. 15.

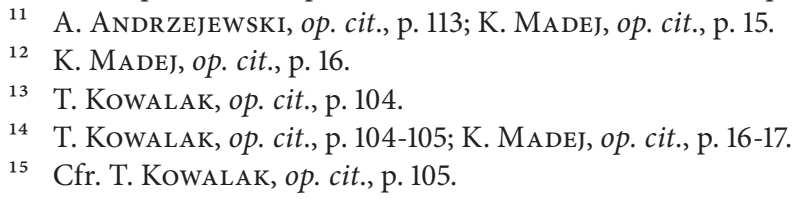


motivated politically and ideologically. As L. Myczkowski observed: «It was an expression of a policy of limiting ownewrship, which gave rise to rules allowing to replace the ownership of land with "perpetual usufruct" and the ownership of a cooperative apartment by the "proprietary right to an apartment" $"$. Indeed, the dogmatic construction of the cooperative member's right to an apartment - which will be discussed in greater detail in the following section - was aimed at enabling individuals to satisfy their housing needs and enjoy protection erga omnes of their apartment, simultaneously, however, preserving the social property of the land on which the cooperative housing was constructed (state property) and the social property of the buidling itself, including the apartments (cooperative property) ${ }^{17}$.

\subsection{THE LEGAL FRAMEWORK}

\subsubsection{Housing cooperatives}

The legal framework of housing cooperatives, including the rights to apartments therein, was laid down in the $1950 \mathrm{~s}^{18}$ and found its final

16 L. Mүсzкошsкi, Nowa ustawa o spółdzielniach mieszkaniowych [The New Housing Cooperatives Act], Zielona Góra 2001, p. 66.

17 R. МАŃко, 'We Do Not Recognise'..., p. 39.

18 See, inter alia, Dekret z dnia 25 czerwca 1954 r. o lokalach w domach spółdzielni mieszkaniowych i w domach jednorodzinnych [Decree of 25 June 1954 on apartments in houses belonging to housing cooperatives and in single-family houses] (Dziennik Ustaw ['Journal of Statutes', official journal for Polish legislation, hereinafter: 'Dz.U.'] no. 31, item 120); Uchwała nr 269 Prezydium Rządu z dnia 8 maja 1954 r.w sprawie spółdzielni mieszkaniowych i zadań spółdzielczości w zakresie budownictwa mieszkaniowego [Resolution no. 269 of the Praesidium of the Government on housing cooperatives and the tasks of the cooperative sector with regards to housing construction] (Monitor Polski ['Polish Monitor', official journal for Polish sub-legislative instruments, hereianfter 'M.P.'], no. A-59, item 792); Uchwała nr 81 Rady Ministrów z dnia 15 marca 1957 r. w sprawie pomocy Państwa dla budownictwa mieszkaniowego ze środków własnych ludności [Resolution no. 81 of the Council of Ministers of 15 March 1957 regarding state aid for housing construction financed from the own resources of the populace] (Dz.U. no. 22, item 157); Uchwała nr 59 Rady Ministrów z dnia 15 marca 1958 r. w sprawie dodatkowej pomocy Państwa dla spółdzielczego budownictwa mieszkaniowego [Resolution no. 59 of the Council of Ministers of 15 March 1958 regarding additional state aid for cooperative housing construction (M.P. no. 22, item 133); Uchwała nr 64 
shape in the Cooperatives Act $1961^{19}$. A recodification of cooperative law in the Cooperatives Act $1980^{20}$ did not lead to a major modification in the dogmatic construction of cooperative rights to apartments ${ }^{21}$.

All housing cooperatives were federated in the Central Union of Housing Construction Cooperatives which, on the one hand, acted as a representative of the cooperative interests in relations with the government, but on the other hand exercised extensive control powers over the cooperatives themselves ${ }^{22}$. New cooperatives could not be organised spontaneously but had to obtain authorisation of the Central Union. From the 1970s onwards, cooperatives were also federated on a regional level in regional housing cooperatives. Housing cooperatives were heavily subsidised by the state which meant that their investment plans were part of the National Economic Plan $^{23}$ which, in turn, led to increased state control over the sector ${ }^{24}$. As a result, cooperatives "increasingly became assimilated to state-owned enterprises and in their

Rady Ministrów z dnia 15 marca 1958 r. w sprawie budownictwa zakładowych domów mieszkalnych i zarządzania nimi [Resolution no. 64 of the Council of Ministers of 15 March 1958 regarding the construction of enterprise-owned housing and the management of such housing] (M.P. no. 26, item 155); Uchwała nr 65 Rady Ministrów z dnia 15 marca 1958 r. w sprawie zapewnienia realnej wartości wkładów na mieszkaniowych książeczkach oszczędnościowych Powszechnej Kasy Oszczędności [Resolution no. 65 of the Council of Ministers concerning the guarantee of a real value of savings placed in housing savings booklets] (M.P. no. 26, item 156).

19 Ustawa z dnia 17 czerwca 1961 r. o spółdzielniach i ich związkach [Act of 17.6.1961 on cooperatives and their unions (Dz.U. no 12, item 161); hereinafter referred to as “Cooperatives Act 1961".

20 Ustawa z dnia 16 września 1982 r. - Prawo Spółdzielcze[Act of 16.9.1982 - the Law of Cooperatives] (Dz.U. no. 30, item 210, hereinafter: “Cooperatives Act 1982").

21 K. Pietrzy kowski, Spółdzielnie mieszkaniowe. Komentarz ${ }^{7}$ [Housing Cooperatives: A Commentary], Warszawa 2013, p. 8-9.

22 K. MADEJ, op. cit., 53ff.

23 K. MADEJ, op. cit., p. 91ff.; I. DrozD-JAŚNIEwICZ, Straty poniesione przez spółdzielczość mieszkaniowa $w$ Polsce $w$ okresie transformacji [The Losses Suffered by the Housing Cooperative Sector During the Period of Transformation] [in:] Historia i przyszłość spółdzielczości mieszkaniowej w Polsce [History and Future of the Housing Cooperative Sector in Poland], ed. Z. Gotfalski, Warszawa 2011, p. 61-62.

24 K. MADEJ, op. cit., p. 32. 
essence became transformed into quasi-state enterprises" 25 . Government control had a wide impact upon the sector, ranging from the sizes of apartments allocated to members (state-determined standard sizes ${ }^{26}$ ) and methods of construction (propagation of low-cost construction technologies ${ }^{27}$ ) to an influence upon the allocation of apartments and the granting of membership. In practice, cooperatives could allocate only a certain fraction of the apartments they built ${ }^{28}$, the remaining part being at the disposal of state enterprises, local government bodies or simply sold against payment of a commercial price in Western currency to the richer strata of society by the "Locum" Office of Foreign Commerce owned by the Central Union ${ }^{29}$.

2.3.2. Two types of cooperative members' rights to apartments: in rem and in personam

As regards the legal forms of allocating apartments to cooperative members there were two possible forms - the 'stronger' proprietary (in rem) right to an apartment and the 'weaker' tenancy (in personam) right. The essential difference between the two depended on the amount of money paid by the right holder - to obtain a proprietary right it was necessary to cover (even if in instalments ${ }^{30}$ ) the whole cost of the

25 J. KLEER, Co dalej ze spółdzielczościa [What to do Further with the Cooperative Sector?], Warszawa 1981, p. 8.

26 K. MADEJ, op. cit., p. 77, 81-82.

27 K. MADEJ, op. cit., p. $84 \mathrm{ff}$.

28 According to data provided by E. Ochendowski, Prawo mieszkaniowe i polityka mieszkaniowa [Housing Law and Housing Policy], Toruń 1980, p. 114, cooperatives allocated ca. 50\% of the housing stock. According to other data, in 1977 cooperatives allocated only $36 \%$ of housing to their members, the remaining $64 \%$ being at the disposal of state-owned companies which financed the construction (32\% apartments), persons directed by the local administration (21\%) and persons directed by other authorities. See T. Janczy к, Spółdzielczość w Polsce Ludowej, Warszawa 1980, p. 150.

29 E. Ochendowski, op. cit., p. 117; T. JANCZYк, op. cit., p. 150.

30 Loans for construction were taken by the cooperative, not by the members, who did not enter into any legal relationship with the bank (K. Pietrzy коwsкi, Spółdzielnie mieszkaniowe. Komentarz ${ }^{5}$, Warszawa 2010, p. 230). 
construction of an apartment ${ }^{31}$; to obtain a tenancy right, it was sufficient to cover a certain fraction $\left(16-20 \%{ }^{32}\right)$, the rest being subsidised by the state. The sum paid by the apartment holder was, in legal terms, a to the cooperative (called, respectively, construction contribution and housing input $^{33}$ ) which was closely linked to the right but survived its extinction. It must be emphasised that with regard to both types of rights, it was always the cooperative that remained the owner of the entire building, including the dwellings ${ }^{34}$.

31 The costs of constructing an apartment was covered by the member in the form of a "construction input" (wkład budowlany), linked to the membership in the cooperative. If for some reason membership in the cooperative and the right to an apartment became extinguished, the construction had to be repaid by the cooperative, e.g. to the heirs of the deceased member. See Coopertatives Act 1961 Art. $148 \$ 1$; later Cooperatives Act 1982, Art. $223 \$ 2$ (according to which the alienation of the proprietary right encompassed ipso iure the alientation of the construction input); Art. 229 (which technically speaking mentions the repayment of the value of the right, and not the input itself, but in the calculation of the value of the right it refers directly to the construction input). The value of the construction input was subject to indexation as provided for by uchwała nr 78 Zarządu Centralnego Związku Spółdzielni Budownictwa Mieszkaniowego z dnia 3 marca 1983 r. w sprawie aktualizacji wartości majątku trwałego i ustalania wkładów w spółdzielniach mieszkaniowych [Resolution no. 78 of the Management Board of the Central Union of Housing Construction Cooperatives of 3 March 1983 regarding the updating of the value of fixed assets and the dermination of inputs in housing cooperatives] («Informacje i Komunikaty CZSBM» 5/1983, item 21). Cfr. Supreme Court resolution of 7 May 1987, Case III CZP 21/87 Teresa W. $v$ Spółdzielnia Mieszkaniowa, «Lex» no. 3370.

32 A. Andrzejewski, op. cit., p. 209.

33 Even if the tenancy right to an apartment became extinguished for some reason, the (former) member or his heirs had a claim to the cooperative to repay the value of the housing input (wkład mieszkaniowy) which was the member's share in the cooperative capital. See Cooperatives Act 1961, Art. $144 \$ 4$; later Cooperatives Act 1982, Art. $218 \$ 4$. Unlike the tenancy right to an apartment, the claim for the repayment of the housing input was alienable inter vivos and subject to succession mortis causa. The Cooperatives Act 1982 made a specific provision for calculating the value of the housing input - it was to correspond to the value of a housing input requested from cooperative members wishing to obtain the attribution of a tenancy right to an apartment of the same size and comparable equipment (Article $218 \$ 4$ sentence 2 ).

34 Cooperatives Act 1961, Art. $135 \$ 2$-3; Cooperatives Act 1982, Art. $204 \$ 2(1)$. 


\subsubsection{The in rem right to a cooperative apartment}

The proprietary right to an apartment ${ }^{35}$ was, in certain aspects, similar to ownership in that it could be alienated inter vivos (sold, exchanged, donated), transferred mortis causa and was attachable in civil enforcement proceedings ${ }^{36}$. Nevertheless, the apartment being owned by the cooperative, the right itself was, strictly speaking, a ius in re aliena ${ }^{37}$ and was, therefore, subject to certain limitations. As I have argued elsewhere, the aim of these restrictions was to further the public interest ${ }^{38}$, of course understood from a specific, collecitivist perspective, typical for actually existing socialsim.

Thus, in order to preserve the principle that an apartment is to serve the satisfaction of housing needs ${ }^{39}$, and cannot be held as a form of capital by individuals, the legislation contained limitations on the number of apartments one person may hold. Therefore, one person could be the holder of only one cooperative member's right to an apartment and be a member of only one housing cooperative ${ }^{40}$. The strong link between the satisfaction of housing needs and the holding of a right to an apartment found their its also in the principle according to which one apartment could be held only by one person (or by a married couple), and co-holdership

35 The Polish terminology of this right evolved over time. Initially it was called spółdzielcze prawo do lokalu w spółdzielniach budowlano-mieszkaniowych (cooperative member's right to an apartment in a housing construction cooperative), then spótdzielcze własnościowe prawo do lokalu w spółdzielniach budowlano-mieszkaniowych (proprietary right of a cooperative member to an apartment in a housing construction cooperative), later, własnościowe spółdzielcze prawo do lokalu w spółdzielniach mieszkaniowych (proprietary right of a cooperative member to an apartment in a housing cooperative) and currently: spółdzielcze własnościowe prawo do lokalu (cooperative member's proprietary right to an apartment).

36 Cooperatives Act 1961, Art. $147 \$ 1$ sentence 1.

37 Ibidem, Art. $147 \$ 2$ sentence 1.

38 R. МаŃко, 'We Do Not Recognise'..., p. 40.

39 Cfr. Article $204 \$ 1$ of the Cooperatives Act 1982: 'The object of the activity of a housing cooperative is the satisfaction of housing needs of members and their families, as well as economic and cultural needs following from residing in a cooperative estate or building.'

40 Cooperative Act 1961, Art. $136 \$ 1$; Cooperatives Act 1982, Art. $206 \$ 1$. 
was excluded ${ }^{41}$. However, a married couple would hold the apartment jointly ${ }^{42}$, This reflected the idea that an apartment serves the satisfaction of housing needs of an individual (if it is a single person) or of a family (married couple). Furthermore, it was also based on the assumption that one apartment is sufficient to satisfy the housing needs of one family ${ }^{43}$. Therefore, if a member acquired more than one right to a cooperative apartment (be it an in rem or in personam right), he was obliged, within 6 months from being called upon by the cooperative to do so, to cure the illegal situation. Failure to do so resulted in the extinguishing of the right acquired later ${ }^{44}$. The same applied to a married couple (which could hold only apartment jointly), unless they proved that they were living in different places for 'justified reasons ${ }^{45}$. Finally, legal persons could not hold the coopeative member's right to an apartment ${ }^{46}$ - as it was conceived for satisfying housing needs, and not for business purposes.

The Supreme Court was strict in interpreting these rules. A member who already acquired a title to a new apartment, but was not moving in, could lose his right because his conduct (i.e. the delaying of his move to the new house) infringed the socio-economic purpose of his right and as such was considered to be an abuse of right (Article 5 of the Civil Code) ${ }^{47}$.

The case-law emphasised the link between the membership in a cooperative and the satisfaction of housing needs. For instance, the Supreme Court ruled ${ }^{48}$ that if a cooperative member who applied for an apartment misrepresented his housing situation by providing false information that his housing needs were not satisfied, whilst in fact he lived in his wife's

41 Cooperatives Act 1982, Art. $206 \$ 1$.

42 Cooperatives Act 1961, Art. 138.

43 Supreme Court (Sad Najwyższy) judgment of 3 May 1985, Case II CR 134/85, «Lex» no. 3120; Supreme Court resolution of 13 May 1986, Case III CZP 16/86 Wacław M. v Spółdzielnia Mieszkaniowa Lokatorsko-Własnościowa w N.T., «Lex» no. 3236.

44 Article $206 \$ 2$ of the Cooperatives Act 1982.

45 Article $206 \$ 3$ of the Cooperatives Act 1982.

46 Article $206 \$ 4$ of the Cooperatives Act 1982.

47 Supreme Court judgment of 22 June 1983, Case IV CR 184/83, «Lex» no. 8551.

48 Judgment of the Supreme Court of 27 January 1984, Case I CR 406/83, «OSP» 5/1985, item 102 . 
house, that individual could be legally expelled from the housing cooperative on the basis of Article $24 \$ 1$ of the Housing Cooperatives Act ${ }^{49}$.

Furthermore, in the case of Aleksandra J.-K. v Nauczycielska Spółdzielnia Mieszkaniowa ${ }^{50}$ the Supreme Court found that a cooperative was entitled to terminate the membership of a member who lived abroad on the legal basis of Article $24 \$ 2$ of the Housing Cooperatives Act ${ }^{51}$. The Court pointed out that:

'The purpose of housing cooperatives is the satisfaction of housing needs of their members (Article 204 of the Law on Cooperatives). The cooperative member is therefore under a duty, following from the [cooperative's] statute, to reside in the cooperative apartment that has been granted to him. Consequently, there are no more reasons for membership of a person who - having her housing needs satsified elsewhere - has ceased to use the cooperative apartment. Therefore, a person who has moved for permanent residence abroad no longer satisfies the conditions necessary to preserve the relationship of membership and may be deleted from the register of members of a housing cooperative (Article $24 \$ 2$ of the 1982 Law on Cooperatives; $\$ 26$ of the statute of the housing cooperative).'

The plaintiff, Aleksandra J.-K., lived in France and later in Zaire (now Congo). However, she visited Poland every year, invested in the apartment and made a written declaration that she intended to return. Neverthelen, the Supreme Court did not take these indications as proof of the merely temporary character of her absence, pointing out that she had a consular passport, i.e. a passport which was issued by a Polish consul to a Polish citizen residing permanently abroad. Consequently, the defendant housing cooperative was correct in deleting her from the

49 Art. $24 \$ 1$ Cooperative Act 1982: 'A member may be expelled from a cooperative if his further membership cannot be reconciled with the provisions of the cooperative's statute or the principles of social life. The statute should determine the reasons for expelling [a member] in more detail.'

50 Judgment of the Supreme Court of 12 April 1984, Case II CR 45/81 Aleksandra J.-K. v Nauczycielska Spółdzielnia Mieszkaniowa, «OSNC»11/1984, item 199.

51 Article $24 \$ 2$ Cooperative Act 1982: 'A member not performing his statutory duties due to reasons for which he is not at fault may lose membership by deletion from the register of cooperative members. The [cooperative] statute should determine the reasons for deletion of [a member from the register] in more detail.' 
list of members, which also had the consequence of extinguishing her right to the apartment. A later judgment of the Supreme Court from 1986 confirmed this line of reasoning ${ }^{52}$.

Furthermore, the legal framework of the cooperative member's proprietary right to an apartment provided for a close tie between holding the right and actual membership in the cooperative. The right was therefore conceived in a collectivist spirit. A right to an apartment could be granted only to a cooperative member ${ }^{53}$. The legislation provided that in the event of the apartment's alienation inter vivos, the transaction became effective only once the acquirer became admitted to the cooperative $^{54}$. The same applied in the event of succession mortis causa ${ }^{55}$. A housing cooperative could, therefore, refuse to admit a person who acquired a cooperative member's proprietary right to an apartment if that person's housing needs were already satisfied elsewhere, e.g. if the acquirer's spouse held a cooperative member's right to an apartment ${ }^{56}$. The collectivist spirit of the in rem right in question was also visible in the rule, provided for by the legislation, whereby the right holder participated not only in the costs of running his apartment and pro rata in the costs of maintaining the building stock of the cooperative (which would be perfectly fine also in an individualist market economy) but also participated financially in the social, cultural and educational activity of the cooperative ${ }^{57}$.

In line with the assumption that the cooperative member's proprietary right to an apartment should not be the object of drawing capital rent,

52 Supreme Court judgment of 8 October 1986, Case I CR 227/86, «Lex» no. 8782.

53 Cooperatives Act 1982, Article 213

54 Cooperatives Act 1961, Art. $147 \$ 1$ sentence 2; later Cooperatives Act 1982, Article $223 \$ 2$ sentence 2 .

55 Cooperatives Act 1961, Art. 150; later Cooperatives Act 1982, Article 228.

56 Supreme Court resolution of 1 February 1989, Case III CZP 110/88 Maria T. v Spółdzielnia Mieszkaniowa w Ł. and Jadwiga S., «Lex» no. 3520.

57 Cooperatives Act 1982, $208 \$ 1$. Cfr. ibidem, Article $204 \$ 1$. These non-housing forms of activity encompassed the running of libraries, cultural centres, clubs, specialist hobby workshops, sports facilities, nurseries, leisure facilities for the elderly and so forth. For statistical data see T. JANCZYK, op. cit., p. 231-232; I. DrOZD-JAŚNIEWICZ, op. cit., p. 66-67. 
the legislation provided that an apartment could be sublet only with the cooperative's consent ${ }^{58}$.

It should also be added that once the legal framework of the proprietary right to an apartment had been laid down, a resolution of the Council of Ministers obliged housing cooperatives to request their members to transfer, by way of a notarial deed, the ownership of their apartments onto the cooperative, in exchange for which the cooperative would grant them a proprietary right ${ }^{59}$. This led to the elimination of apartment ownership in cooperative housing and its replacement with the new, socialist right in rem.

\subsubsection{The in personam right to a cooperative apartment}

Although not a proper subject of the present paper, which focuses on the cooperative member's proprietary right to an apartment, a few words need to be said about its 'junior sibling', the cooperative member's tenancy right to an apartment ${ }^{60}$ which, in contrast to the in rem 'senior' right, was itself merely a right in personam. In contrast with the proprietary right (in rem), the tenancy right was decommodified: it could

58 Cooperatives Act 1982, Art. $217 \$ 2$.

59 L. Myczkowski, op. cit., p. 66-67. See uchwała Rady Ministrów z dnia 18 grudnia 1965 r. w sprawie przejęcia niektórych budynków spółdzielni mieszkaniowych na własność Państwa, zasad rozliczeń z tego tytułu oraz uregulowania niektórych innych spraw z zakresu spółdzielni budownictwa mieszkaniowego [Resolution of the Concil of Ministers of 18.12.1965 regarding the transfer of ownership of captain housing cooperative buildings to the State, settlements connected thereto and regulation of other aspects regardin housing cooperative] (M.P. no. 72, item 406). Cooperatives which would refuse to follow this procedure where threatened by the government with the prospect of not receiving a right of perpetual usufruct to the land on which their buildings stood (the said land having been nationalised as from 21 November 1945), which would mean that they would lose their buildings completely (L. Mүсzкоwski, op. cit., s. 67). Cfr. Dekret z dnia 28 października 1945 o własności i użytkowaniu gruntów na obszarze m.s.t Warszawy [Decree of 28.10.1945 regarding the ownership and use of land within the bounds of the Capital City of Warsaw] (Dz.U. no. 50, item. 279).

60 According to the Cooperatives Act 1982 it was called 'lokatorskie prawo do lokalu' (tenancy right to an apartment); under current legislation it is called 'spótdzielcze lokatorskie prawo do lokalu' (cooperative member's tenancy right to an apartment). The word 'lokator' means 'tenant' (in the context of rented housing). 
not be alienated inter vivos (neither sold, nor donated) and it was not subject to succession mortis causa ${ }^{61}$. However, the rules of cooperative law required that upon the right holder's death the right be assigned to a next of kin who was living together with the deceased person ${ }^{62}$. Although formally this was not a form of succession, in practice it partly fulfilled the socio-economic functions of inheritance towards e.g. the spouse or the children of the deceased cooperative member.

As from 1972 it was permissible to convert a tenancy right into a proprietary right against the payment of the difference between the construction input and the housing input ${ }^{63}$. The right to conversion was formally enshrined in the Cooperatives Act 1982, which provided that a cooperative member needed to make a written request, pay the housing input (i.e. the value of the construction of the apartment), upon which the cooperative was obliged, within the deadline specified in its statute, to convert the tenancy (in personam) right into a proprietary (in rem) right ${ }^{64}$. However, a housing cooperative's statute (i.e. its internal rules) could specify situations in which it was entitled to refuse to proceed with the conversion ${ }^{65}$. Furthermore, the statute of a cooperative could

61 Cooperatives Act 1961, Art. $144 \$ 1$; later Cooperatives Act 1982, Article $218 \S 1$.

62 Cooperatives Act 1961, Art. 145 (according to which if a member's membership expired, a priority in admitting a new member and granting him a tenancy right to an apartment was given to the spouse, children and other 'close relatives' [osoby bliskie] if they lived together with the former member; if many entitled persons made a request, it was up to the cooperative to make a choice); later Cooperatives Act 1982, Articles 220 (according to which, upon death of a spouse who was entitled to a tenancy right to an apartment, the right was extinguished and then a new right to the same apartment established in favour of the surviving spouse) and Article $221 \$ 1$ (according to which, should the hypothesis provided for in Article 220 not be realised, the following had the right to request that a tenancy right to an apartment be established in their favour: the spouse, the children and other 'close relatives' - provided that they lived together with the deceased).

63 M. Cesarski, Dorobek materialny spółdzielczości mieszkaniowej w Polsce [The Material Output of the Housing Cooperative Sector in Poland] [in:] Historia i przyszłość spółdzielczości mieszkaniowej w Polsce [History and Future of the Housing Cooperative Sector in Poland], ed. Z. Gotfalski, Warszawa 2011, p. 29.

64 Cooperatives Act 1982, Article $219 \$ 1$.

65 Cooperatives Act 1982, Article $219 \$ 2$. 
provide that in houses for disabled persons, single persons and other houses with a special purpose the tenancy rights to apartments were excluded from conversion ${ }^{66}$.

It must be emphasised that whilst a tenancy right could be upgraded (against payment), this process did not work the other way round (a proprietary right could not be 'downgraded' to a tenancy right ${ }^{67}$ ) nor did it go any further (a proprietary right could not be 'upgraded' to individual ownership ${ }^{68}$ ).

In practice, tenancy rights to apartments - representing the social housing sector, subsidised by the state-socialist welfare state, dominated. According to the statistical data, as of $1977,91 \%$ of cooperative flats were held under tenancy rights and just $9 \%$ under proprietary rights ${ }^{69}$ and as of 1989 the number of proprietary apartments doubled, with the numbers, respectively $78 \%$ and $22 \%^{70}$. It is worth mentioning that in general, cooperatives held approximately $25 \%$ of housing stock in towns and the same proportion of the population lived in $\mathrm{it}^{71}$.

\section{The Situation after the Transformation}

\subsection{THE IMPACT OF THE TRANSFORMATION UPON HOUSING POLICY}

After 1989, the political elites of Poland opted for the neoliberal variety of a market economy ${ }^{72}$. This had an immense impact upon the conceptions and practices of the welfare state ${ }^{73}$. In consequence, assisting citizens

66 Cooperatives Act 1982, Article $219 \$ 3$.

67 E. OCHendowski, op. cit., p. 109.

68 A. MĄCZyŃski, Dawne i nowe instytucje polskiego prawa mieszkaniowego [New and Old Institutions of Polish Housing Law], «Kwartalnik Prawa Prywatnego» 11.1/2002, p. 88 .

69 T. JANCZYK, op. cit., p. 150.

70 M. CESARSKi, op. cit., p. 29.

71 T. JANCZYK, op. cit., p. 151.

72 D. Ost, The Defeat of Solidarity: Anger and Politics in Postcommunist Europe, Cornell 2006, p. 61ff; J. Hardy, Poland's New Capitalism, London-New York, p. $31 \mathrm{ff}$.

73 J. HARDY, op.cit., p. 115ff. 
in procuring a dwelling satisfying their housing needs was no longer treated as a duty of the state (as in a socialist or capitalist welfare state ${ }^{74}$ ) but was consciously and intentionally left to market mechanisms ${ }^{75}$. State subsidies to cooperatives building tenancy apartments were withdrawn ${ }^{76}$, and central economic planning was dismantled. Cooperatives were no longer federated on an obligatory basis ${ }^{77}$. Those legal institutions of actually existing socialism which survived - including the legal framework of cooperative housing - were brought into an entirely different context.

\subsection{Continued EXISTENCE OF THE COOPERATIVE PROPRietary} RIGHT TO AN APARTMENT AFTER 1989

The object of my present inquiry is the identification of the preconditions of the continued existence of the proprietary right to an apartment - a survival of the period of actually existing socialism ${ }^{78}-$ in

74 Social housing has played an important role in the welfare states of the Netherlands, Sweden, Austria and France, see e.g. P. Balcin (ed.), Housing Policy in Europe, Abington 1996, p. 69ff.

75 A. Kuper, Spółdzielnie mieszkaniowe w Polsce - dzieje i przesłanki przetrwania [Housing Cooperatives in Poland: History and Conditions for Survival] [in:] Spółdzielnie mieszkaniowe - relikt przeszłości czy szansa na przyszłość [Housing Cooperatives: A Relic of the Past or a Chance for the Future?], ed. Z. Gotfalski, Warszawa 2006, p. 42; I. Drozd-Jaśniewicz, op. cit., p. 74.

76 I. Drozd-JaśniewiCz, op. cit., p. 74; M. Cesarski, op. cit., p. 32. Cfr. Najwyższa Izba Kontroli [Supreme Chamber of Control], Informacja o wynikach kontroli: Realizacja zadań w zakresie gospodarki mieszkaniowej przez organy administracji rzadowej i jednostki samorzadu terytorialnego [Information About Control Results: Realisation of Tasks in the Field of Housing by Bodies of Governmental Administration and Local Government Bodies], document no. 170/2011/P/11/108/KIN, Warszawa 10.1.2012, available at <http://www.nik.gov.pl/plik/id,3581,vp,4565.pdf>, last accessed 10 November 2015.

77 Act of 23.10.1987 (Dz.U. no. 33 item 181), art. 11(1). See also Act of 20.1.1990 (Dz.U. no. 6 item 36$)$.

78 Although in the Polish context this type of arrangement under which a cooperative owns the building and the member holds a right to use an apartment (but is not an owner) is a survival of the period of actually existing socialism, it must be kept in mind that similar legal arrangements exist in capitalist countries which had never experienced actually existing socialism. Housing cooperatives actually originated in the United States where the first such organisations were established at the end of the 19th century (C. vaN DER Merwe, Apartment Ownership, Leiden 1994, p. 185). See Uniform Common Interest 
contemporary Poland. It should be recalled at the outset that proprietary rights to apartments in cooperative estates could be established - as regards newly built stock - until 2007 (with a 20 -month interval between April 2001 and January 2003) $)^{79}$, i.e. during a period of 18 years following Poland's transition to a market economy.

In existing buildings that had been constructed on land whose legal status remains "unregulated" be established at the request of holders of tenancy rights who wanted to "upgrade" their right; such a conversion was permissible until the end of $2012^{81}$. It must be added that despite repeated legislative proposals ${ }^{82}$. Proprietary rights to cooperative flats have not been converted into individual

Ownership Act (1994), §1-103(10), (hereinafter: UCIO Act 1994). The American model of housing cooperatives has been the object of reception inter alia in Australia (C. VAN DER Merwe, op. cit., p. 181). Within Western Europe, rights to apartments in cooperatives are known in Sweden, Norway and Finland (C. VAN DER Merwe, op. cit., p. 7). As a matter of fact, Norway does not even seem to have special rules on apartment ownership (ibid.) Swedish cooperatives active in the housing sector are divided into two types - housing cooperatives (bostadsrättsföreningar) and cooperative rental associations (kooperativ hyresrättsföreningar); in both types buildings (including the apartments) are owned by the cooperative; in the first type of cooperatives members have a share entitling them to use a specific apartment (which can be sold, inherited etc.); in the second type of cooperative members do not have such a right but are the cooperative's tenants. Swedish housing cooperatives are non-profit operators. For details see: B. BENGTsson et al., Swedish Law: a survey (Lund: Juristforlaget, 1994), p. 282; L. CARLSON, The Fundamentals of Swedish Law, Lund 2009, p. 258, 282-283, 336, 439.

79 To be precise, from 24 April 2001 (entry into force of the act of 15.12.2000, Dz.U. no. 4, item 27, hereinafter: "Housing Cooperatives Act 2000"). The possibility of creating such rights was restored as of 15 January 2003 (entry into force of Act of 19.12.2002, Dz.U. no. 240, item 2058).

80 This concept basically means that the cooperative is neither the owner nor a perpetual usufructuary of the land.

81 Ustawa z dnia 18 grudnia 2009 r. o zmianie ustawy o spółdzielniach mieszkaniowych oraz o zmianie niektórych innych ustaw [Act of 18 December 2009 amending the Housing Cooperatives Act and other acts] (Dz.U. no. 223, item 1779), Article 6. See E. Bończak-Kucharczyк, Spółdzielnie mieszkaniowe. Komentarz ${ }^{3}$ [Housing Cooperatives: Commentary], Warszawa 2013, p. 381-383.

82 See e.g. legislative proposal submitted in 1994 (Sejm print no. II.663 of 2 July 1994). 
ownership ipso iure. Such a conversion can take place only at the right holder's request and after the repayment of the costs of the construction of the apartment ${ }^{83}$. However, if the legal status of the land on which the cooperative house is built is unregulated, a transformation cannot take place $^{84}$. Such a situation is not infrequent in practice ${ }^{85}$. Taking this fact into account, it is possible that proprietary rights to apartments, although abolished pro futuro, will still continue to function in practice for many years. It should be added that the sale, donation or inheritance of a proprietary right to an apartment does not affect its legal nature (it does not become converted into ownership by virtue of any such legal event ${ }^{86}$.

Regardless of the ongoing convergence between the proprietary right to an apartment and the ownership of apartments, in practice there are still a number of significant differences ${ }^{87}$. First of all, the owner of an apartment may change its function, whilst the holder of a proprietary right needs to receive the cooperative's consent for such a change (e.g. from housing premises to business premises). Secondly, the owner of an apartment is entitled to a share in the land beneath the building and the common parts of the building (e.g. staircase, roof, corridor, external walls), whilst the holder of a proprietary right is not. With regard to the cooperative's bankruptcy or liquidation or attachment of its assets, however, it should be mentioned that according to Article $17^{18}(1)$ of the Housing Cooperatives Act (as modified on 22 July 2005), if the building is acquired, as a result of liquidation, bankruptcy or enforcement

83 Originally Housing Cooperatives Act 2000, art. 39, now Art. $17^{14}$ of the same Act. Cfr. E. BońcZak-KuCharCZyk, op. cit., p. 451ff.

84 Currently: Housing Cooperatives Act 2000, Art. $17^{14}(1)^{1}$. Cfr. E. BońcZaK-KuCHARCZyK, op. cit., p. 458. This is linked with the principle of Polish property law that individual ownership of an apartment must always be linked with a share in the ownership of the land on which the building stands (K. Pietrzy коwsкi, Spółdzielnie ${ }^{7} . .$, p. 269).

85 Pietrzy kowski, Spółdzielnie 7 ..., p. 256.

86 E. BońCZaK-KuCharCZyK, op. cit., p. 377.

87 T. Skotarczak, M. Śpiewak-Szyjka, 'Spółdzielnie mieszkaniowe w nowym otoczeniu społeczno-gospodarczym', [in:] Spółdzielnie mieszkaniowe: Dylematy funkcjonowania i rozwoju, ed. T. SкотARCZAK (C.H. Beck, 2015), p. 18. 
proceedings by an entity which is not a housing cooperative, the in rem right is converted ipso iure into the right of ownership of the apartment.

Despite the aforementioned option of "converting" the cooperative proprietary right into full ownership, many millions of such rights are still in existence. As of 2010, there were still 2.6 million cooperative apartments ${ }^{88}$, a vast majority of them held under the cooperative member's proprietary right ${ }^{89}$. In comparison, until 2010 only 700,000 cooperative apartments, hitherto held under the cooperative property title, had been transformed into objects of full private ownership ${ }^{90}$. The fact that the majority of holders of cooperative proprietary rights to apartments do not transform their right into full ownership stems from various reasons, among them the costs of such an operation and the fact that both ownership and cooperative property rights have their respective advantages and disadvantages in practice, often depending on the particular circumstances of a given housing cooperative or condominium ${ }^{91}$.

Although the costs of conversion have been reduced as a result of an amendment enacted in $2007^{92}$, the cooperative member still needs to repay, if applicable, the original loan taken by the cooperative to build

88 M. CESARSKi, op. cit., p. 42.

89 M. Cesarski, op. cit., p. 8.

90 M. Cesarski, op. cit., p. 43.

91 Cfr. I. Foryś, M. NowAK, Społdzielnia czy wspólnota? Zarządzanie zasobami mieszkaniowymi [Cooperative or Condominium? Housing Stock Management] (Warszawa: Poltext, 2012), p. 202.

92 Originally Article $17^{14}$ (1)(1)-(4) - introduced by Act of 19 December 2002 (Dz.U. No. 240, item 2058) which entered into force on 15 January 2003 - provided that the member needs to repay: (1) a pro rata part of the cooperative's obligations connected to the construction of the building, and in particular the appropriate part of the cooperative's loan with interest; (2) a supplementation of the construction input resulting from the modernisation of the building; (3) a pro rata part of the cooperative's obligations arising from credit and loans taken for the financing of the costs of renovating the building; (4) repayment of all debts arising from the duty to make payments for the use of the apartment and other fees due to the cooperative. Items (2) and (3) on the list of payments to be made prior to the conversion into full ownership were deleted by the Act of 14 June 2007 (Dz.U. No. 125, item 873) which entered into force as from 31 July 2007 (consequently item (4) was renumbered to (2)). 
his apartment which, in some cases, may be a deterring factor, especially if balanced against the immediate advantages of conversion.

\subsection{MODIFICATIONS OF THE LEGAL FRAMEWORK OF THE RIGHT}

As I indicated in section 2, under actually existing socialism the proprietary right to an apartment, although similar in certain respects to ownership, was nevertheless different. The main elements differentiating proprietary rights to apartments from individual ownership could be summarised under the heading of limitations to the commodification of such rights.

The most straightforward method of commodifying housing would be the transformation of existing legal titles (both the in rem and in personam rights to apartments) into individual ownership. Important as it is, what is of interest for me in this paper is not the aforementioned conversion of proprietary rights to apartments into individual ownership, be it ipso iure (which is not possible) or on the basis of a cooperative member's request (as described above), but the survival of the former rights under the new socio-economic system.

I contend that the factors allowing for its survival have been twofold. First of all, the adaptation of the content of the right to the new conditions, i.e. the removal of the obstacles to its commodification, ultimately leading to a far-reaching approximation to individual apartment ownership. Secondly, practical difficulties regarding the transformation of in rem rights into dominium linked to the essential elements of the legal construction of flat ownership in Poland and the status of land on which cooperative buildings had been constructed.

As regards the first aspect - the commodification - it should be mentioned that this process was accomplished during the 1990s and early 2000s as a joint enterprise of the legislature and judiciary. As early as 1991 the legislature permitted the encumbrance of a proprietary right to a cooperative with mortgage (hipoteka) ${ }^{93}$ which should be linked to the growing role of the commercial banking sector in the financing of

93 Ustawa z dnia 25 października 1991 r. o zmianie ustawy - Kodeks cywilny oraz ustaw - o księgach wieczystych i hipotece, Prawo spółdzielcze, Kodeks postępowania cywilnego, Prawo lokalowe [Act of 25 October 1991 amending the Civil Code, the Land 
housing. In 1994 the principle of that one person (or married couple) could hold only one proprietary right to an apartment was abolished ${ }^{94}$, permitting the transformation of a cooperative apartment into an investment asset. In 2001 the co-holdership of the proprietary right became possible ${ }^{95}$, further detaching the right from the idea of satisfying housing needs (of a family) and treating it as any other object of property rights. From that year on also minors - even living with their parents, ergo not having housing needs of their own - could acquire cooperative rights in apartments ${ }^{96}$.

The holdership of an apartment has been separated from membership in the cooperative ${ }^{97}$, effectively depriving the cooperative of any means of controlling the inflow of inhabitants into its housing stock. For the sake of full commodification of cooperative apartments, Polish housing cooperatives have been deprived of this right with regard to proprietary apartments, apartments under individual ownership and the subletting of such apartments. This could be contrasted, inter alia, with the legal situation in Sweden, where in proprietary cooperatives a cooperative

Register and Mortgage Act, the Cooperatives Act, the Code of Civil Procedure and the Housing Law] (Dz.U. no. 115, item 496).

94 Ustawa z dnia 7 lipca 1994 r. o zmianie ustawy - Prawo spółdzielcze oraz o zmianie niektórych ustaw [Act of 7 July 1994 amending the Cooperatives Act and certain other acts] (Dz.U. no. 90, item 419).

95 Decision of the Polish Consitutional Court of 25.2.1999 in Case K 23/98 Re Principles of Inheriting a Cooperative Proprietary Right to an Apartment, «OTK» Zb.Urz. 1999, no. 2, item 25; Decision of the Polish Consitutional Court 29.6.2001 in Case K 23/00 Re Succession, Subletting and Right of Ownership of a Cooperative Apartment, «OTK» Zb.Urz. 2001, no. 5, item 124. Cfr. E. BońcZAK-KuсHARCZYк, op. cit., p. 396.

96 Housing Cooperative Act 2000, art. 3.

97 Decision of the Polish Consitutional Court of 21.5.2001 in Case SK 15/00 Anna W. v Zarząd Spółdzielni Mieszkaniowej w Bochni, «OTK» Zb.Urz. 2001, no. 4, item 85; Decision of the Polish Constitutional Court of 30.3.2004 in Case K 32/03 Re Housing Cooperatives Act 2000, OTK Zb.Urz. 2004, no. 3A, item 22; Decision of the Polish Supreme Court of 28.4.2006 in Case V CSK 42/06 Edward M. v Spółdzielnia Mieszkaniowa Lokatorsko-Własnościowa w J., «Lex» no. 240585. Cfr. G. BIEniek, Nieruchomości spółdzielni mieszkaniowych [in:] Nieruchomości. Problematyka prawna [Immovables: Legal Issues], ed. G. Bieniek, S. Rudnicki, Warszawa, p. 283; E. Bończak-Kucharczyk, op. cit., p. 400-401. 
member's right to an apartment can be sold or inherited, however the buyer or successor must be admitted as a new member by the cooperative board ${ }^{98}$. In fact, the cooperative board may deny membership if there is a specific ground for that in the cooperative's statute or if the candidate for membership does not have the financial capacity to pay the monthly fees ${ }^{99}$. This allows cooperatives to manage their financial policy (by admitting only financially sustainable members) and control the personal substratum of membership.

As T. Skotarczak observed, the convergence of the proprietary right to an apartment with the full ownership of apartments is a fact as regards their socio-economic function ${ }^{100}$. In his view, "[t]he continued existence of the cooperative proprietary right to an apartment as a limited real right is justified above all by historical circumstances [...] and by the lack of willingness on the part of entitled parties to embark on the transformation procedure ${ }^{101}$. However, a different issue, which will not be analysed in more detail in the present paper, concerns quite different forms of governance in housing cooperatives (which can count many thousands of members) and condominia (which usually count less than 100 members), not only due to the differences of size, but also a different legal framework ${ }^{102}$.

\section{Conclusions: Change of Social Function as a Result of THE SOCIO-ECONOMic Transformation}

The cooperative member's proprietary right to an apartment, which was analysed in the present article, is an example of a 'legal survival' of the period of actually existing socialism in Polish private law. The right was created in the 1950s, when the communists ruling Poland did not

\footnotetext{
98 B. Bengtsson et al., op. cit., p. 283.

99 Ibid., p. 283.

100 T. SкотавсZaк, Nowe funkcje spółdzielni mieszkaniowych, [in:] Spółdzielnie mieszkaniowe......, ed. T. SкотARCZAK, p. 52-53.

101 T. SкотARCZAK, op. cit., p. 52.

${ }^{102}$ Ibid., p. 53.
} 
want citizens to be able to acquire the right of ownership in apartments, but were rather concerned about preserving the 'socialised ownership' of land and buildings. Hence, the cooperative member's proprietary right to an apartment was constructed as an in rem right to an apartment, whilst the apartment was not a separate thing (res), but the in rem right encumbered the res in the form of the housing cooperative's building (ius in re aliena). To complicate things further, as a rule the housing cooperative owned only the building, whilst the land was owned by the state. This led to a three-tier construction: the land was owned by the state; the cooperative held a right of perpetual usufruct (użtkowanie wieczyste) over the land and simultaneously owned the building; and the cooperative member held an in rem right to use a specific apartment within that buidling.

The dogmatic construction of the cooperative member's proprietary right to an apartment is a clear reflection of its socio-economic functions, typical for the reality of actually existing socialism and its collectivist ideology. The underlying premise was that an apartment serves the satisfaction of housing needs and may not be used as a form of capital. Therefore, one individual (or one family) could hold only one apartment, the right to an apartment was strictly connected to membership in the cooperative, and so forth.

The transformation of 1989 had an immense impact upon the cooperative member's proprietary right to an apartment. Prima facie one could have expected that the right would be removed from the legal order altogether and replaced with full ownership of apartments, just as in the 1950s owners of apartments in cooperative housing were forced by a governmental resolution to give up their right of ownership in exchange for the in rem right to their apartment. However, despite legislative efforts going in that direction, this did not happen. What is more, cooperative rights could even be established in newly erected buildings for a long time (until 2007), whilst tenancy rights to apartments (in personam) could be transformed into cooperative member's proprietary rights to an apartment until the end of 2012.

The continued existence of the cooperative right to an apartment justifies the question of the possibility of such a continuity, despite the 
changed socio-economic and political circumstances. In other words, how has it been possible for this legal institution - of a clearly state-socialist pedigree - to survive until today? For, according to available statistical data, there are still some 2 million such rights. And although today holders of such rights are formally entitled to request the cooperative to upgrade their right to full ownership, many people do not undertake this step and it is possible that such rights may continue to exist for decades to come.

Without entering into a political analysis why the bills submitted to the Polish Parliament transforming the right into full ownership ipso iure never became legal reality, I wish to enquire here why a socialist legal form could continue its existence under conditions of a market economy. Following Karl Renner, I posit, as I have already suggested earlier ${ }^{103}$, that the key factor enabling the survival of a prima facie outdated (in casu, state-socialist) legal institution lies above all in its functionality ${ }^{104}$ in the new socio-economic environment.

Initially, the cooperative member's in rem right to an apartment fulfilled two functions. Firstly, it allowed the state to retain control of property in real estates (the land remained state-owned, whereas the building and apartments therein were owned by the state-controlled housing cooperatives). This arrangement had a triple function: political, ideological, and economic. Individuals would acquire only a limited property right in the apartment which they financed entirely from their own resources, instead of acquiring full ownership rights as in a condominium, which was in contrast to the system of cooperative housing in Poland prior to World War II, when those cooperative members who had financed their housing entirely would acquire full ownership of the apartment in question.

Secondly, the institution in question fulfilled the function of granting individuals a stable title in their apartment, in exchange for covering the costs of its construction. This was a socio-economic function. After

\footnotetext{
103 R. Mańko, Legal Survivals..., p. 27; Idem, 'We Do Not Recognise’..., p. 33.

${ }^{104}$ For a detailed analysis on the notion of functionality of legal institutions in their socio-economic environment see in particular R. MAŃko, Legal Survivals..., p. 23-24.
} 
1989, it was exactly this latter function which was retained. However, the first of the two original functions (of enabling the state to control property) was abolished, which is a clear consequence of the new political, ideological and economic circumstances.

Furthermore, on top of the social functions fulfilled under the system of the command-distributive economy of actually existing socialism, the legal survival in question came to fulfil entirely new social functions, typical for a market economy. Following the transformation of 1989, cooperative rights to apartments could be treated as investment assets, as means for locating savings, as assets for speculation, as well as an instrument for drawing capital rent (by renting out the property to a third party). All these economic functions, typical for market economies but fundamentally inconsistent with the state-socialist system of a command-distributive economy, were introduced after 1989.

However, the original legal framework of the legal survival in question had been designed precisely to prevent its application for such economic purposes. Exactly for this reason the legal framework of the cooperative proprietary right to an apartment had to undergo an adaptation. This occurred both at the legislative and judicial level, namely through judgments of the Constitutional Court which declared unconstitutional certain provisions of cooperative law that prevented the extension of the social function of the cooperative right to an apartment.

The answer to the question regarding the endurance of this legal institution in post-1989 Poland lies, therefore, in its adaptation to the new conditions. This adaptation enabled the modification of the social function of the institution by effectively dismantling all the limitations which differentiated it from ownership. However, despite this undeniable convergence between the cooperative member's proprietary right to an apartment and the right of ownership of an apartment, the former still constitutes a distinct legal title - a remnant of Poland's socialist past, alongside the 'principles of social life ${ }^{105}$, the right of perpetual

${ }^{105}$ In Polish: 'zasady współżycia społecznego'. For more details see R. MAŃко, Quality of Legislation Following a Transition from Really Existing Socialism to Capitalism: A Case Study of General Clauses in Polish Private Law, [in:] The Quality of Legal Acts and Its Importance in Contemporary Legal Space, ed. J. RozENFELDS ET AL., Riga 2012. 
usufruct ${ }^{106}$ or the prosecutor's all-encompassing locus standi in civil proceedings ${ }^{107}$.

The Cooperative Member's Proprietary Right to an Apartment: a Legal Survival of The Period of Actually Existing Socialism in Polish Private Law

SPÓ£DZIELCZE WŁASNOŚCIOWE PRAWO DO LOKALU W POLSKIM PRAWIE PRYWATNYM: RELIKT PRAWNY EPOKI SOCJALIZMU REALNEGO

Streszczenie

Spółdzielcze własnościowe prawo do lokalu jest przykładem reliktu prawnego epoki socjalizmu realnego, który przetrwał pomimo przemian społeczno-gospodarczych, politycznych i prawnych zapoczątkowanych w 1989 r. Omawiane prawo zostało powołane do życia w latach 50. XX w., a swoją formę ustawową uzyskało w $1961 \mathrm{r}$. Jego powstanie było uwarunkowane istniejącymi w minionym okresie stosunkami politycznymi i gospodarczymi, a także względami ideologicznymi. Prawo to miało bowiem zastąpić odrębną własność lokali, przy równoczesnym zapewnieniu uprawnionym możliwości władania, za pomocą prawa in rem, lokalem, którego budowę sfinansowali $\mathrm{z}$ własnych środków. Ramy prawne omawianej instytucji w okresie PRL nacechowane były elementami „uspołeczniającymi”, m.in. uniemożliwiając nabycie więcej niż jednego prawa przez tę samą rodzinę, uzależniając podnajęcie lokalu od zgody spółdzielni, czy też wtórne nabycie prawa mortis causa i inter vivos od przyjęcia nabywcy w poczet członków spółdzielni. Po roku 1989 spółdzielcze własnościowe prawo do lokalu nie zostało automatyczne przekształcone w odrębną własność lokali, czego można by się spodziewać w kontekście transformacji od gospodarki nakazowo-rozdzielczej

${ }^{106}$ In Polish: 'prawo użytkowania wieczystego'. For more details see R. MAŃko, 'We Do Not Recognise'..., p. 41-42, 53-54.

107 For more details see R. MAŃкo, Is the Socialist Legal Tradition 'Dead and Buried?' The Continuity of the Certain Elements of Socialist Legal Culture in Polish Civil Procedure, [in:] Private Law and the Many Cultures of Europe, ed. T. Wilhelmsson ET AL., Alphen aan den Rijn 2007, p. 92-94. 
do gospodarki rynkowej. Pomimo postępującej konwergencji pomiędzy spółdzielczym własnościowym prawem do lokalu oraz odrębną własnością lokalu, widocznej zarówno w warstwie prawnej, jak też w szczególności w zakresie funkcji społeczno-gospodarczych, prawo to istnieje nadal w obrocie stanowiąc relikt prawny epoki socjalizmu realnego.

Słowa kluczowe: prawo spółdzielcze, prawo mieszkaniowe, prawo socjalistyczne, relikty prawne

Keywords: cooperative law, housing law, socialist law, legal survivals

\section{Bibliography:}

Andrzejewski A., Zarys polityki mieszkaniowej [An Outline of Housing Policy], Warszawa 1979

Balcin P. (ed.), Housing Policy in Europe, Abington 1996

Bengtsson B. et al., Swedish Law: a survey, Lund 1994

Bieniek G.. Nieruchomości spółdzielni mieszkaniowych [Housing Cooperatives'

Immovbless], [in:] Nieruchomości. Problematyka prawna [Immovables:

Legal Issues], ed. G. Bieniek, S. Rudnicki, Warszawa 2005

BońCZak-Kucharczyк E., Spółdzielnie mieszkaniowe. Komentarz ${ }^{3}$ [Housing

Cooperatives: Commentary], Warszawa 2013

Butler W.E., Soviet law, London 1983

CARLSON L., The Fundamentals of Swedish Law, Lund 2009

Cesarski M., Dorobek materialny spółdzielczości mieszkaniowej w Polsce [The Material Output of the Housing Cooperative Sector in Poland], [in:] Historia i przyszłość spółdzielczości mieszkaniowej w Polsce [History and Future of the Housing Cooperative Sector in Poland], ed. Z. Gotfalski, Warszawa 2011 DrozD-JAśNIEWICZ, Straty poniesione przez spóldzielczość mieszkaniowa w Polsce $w$ okresie transformacji [The Losses Suffered by the Housing Cooperative Sector During the Period of Transformation], [in:] Historia i przyszłość spółdzielczości mieszkaniowej w Polsce [History and Future of the Housing Cooperative Sector in Poland], ed. Z. Gotfalski, Warszawa 2011

Foryś I., NowaK M., Społdzielnia czy wspólnota? Zarządzanie zasobami mieszkaniowymi [Cooperative or Condominium? Housing Stock Management], Warszawa 2012

Hardy J., Poland's New Capitalism, London-New York 2009

Janczy T., Spółdzielczość w Polsce Ludowej, Warszawa 1980 
KLEER J., Co dalej ze spółdzielczościa [What to do Further with the Cooperative Sector?], Warszawa 1981

Kowalak T., Dorobek spółdzielczości w trzydziestoleciu Polski Ludowej [The Output of the Cooperative Sector during the Three Decades of People's Poland], Warszawa 1975

Kuper A., Spółdzielnie mieszkaniowe w Polsce - dzieje i przesłanki przetrwania [Housing Cooperatives in Poland: History and Conditions for Survival], [in:] Spółdzielnie mieszkaniowe - relikt przeszłości czy szansa na przyszłość [Housing Cooperatives: A Relic of the Past or a Chance for the Future?], ed. Z. Gotfalski, Warszawa 2006

MąCZYŃski A., Dawne i nowe instytucje polskiego prawa mieszkaniowego [New and Old Institutions of Polish Housing Law], «Kwartalnik Prawa Prywatnego» 11.1/2002

MAdej K., Spółdzielczość mieszkaniowa. Władze PRL wobec niezależnej inicjatywy spółdzielczej [Housing Cooperatives: The Authorities of the Polish People's Republic Towards Independent Cooperative Initiative], Warszawa 2003

Malinowski B., A Scientific Theory of Culture and Other Essays, New York $1961[1944]$

Mańko R., 'We Do Not Recognise Anything "Private": Public Interest and Private Law Under the Socialist Legal Tradition and Beyond, [in:] Private Interest and Public Interest in European Legal Tradition, ed. B. SITEK ET AL., Olsztyn 2015

Mańko R., Is the Socialist Legal Tradition 'Dead and Buried?' The Continuity of the Certain Elements of Socialist Legal Culture in Polish Civil Procedure, [in:] Private Law and the Many Cultures of Europe, ed. T. Wilhelmsson ET AL., Alphen aan den Rijn 2007

Mańko R., Legal Survivals: A Conceptual Tool for Analysing Post-Transformation Continuity of Legal Culture, [in:] Tiesību efektivitāte postmodernā sabiedrība [Effectivness of Law in post-modern Society], ed. J. RozENFELDS ET AL., Riga 2015

Mańko R., Quality of Legislation Following a Transition from Really Existing Socialism to Capitalism: A Case Study of General Clauses in Polish Private Law, [in:] The Quality of Legal Acts and Its Importance in Contemporary Legal Space, ed. J. RozEnfELDS ET AL., Riga 2012

Mańko R., Relikty w kulturze prawnej. Uwagi metodologiczne na tle pozostałości epoki socjalizmu realnego w polskim prawie prywatnym, "Przegląd Prawa i Administracji» 52/2015 
Myсzкошsкi, L. Nowa ustawa o spółdzielniach mieszkaniowych [The New Housing Cooperatives Act], Zielona Góra 2001

NajWyższa IzBa Kontroli [Supreme Chamber of Control], Informacja o wynikach kontroli: Realizacja zadań w zakresie gospodarki mieszkaniowej przez organy administracji rzadowej $i$ jednostki samorzadu terytorialnego [Information About Control Results: Realisation of Tasks in the Field of Housing by Bodies of Governmental Administration and Local Government Bodies], document no. 170/2011/P/11/108/KIN, Warszawa 10.1.2012, available at $<$ http://www.nik.gov.pl/plik/id,3581,vp,4565.pdf $>$, last accessed 10 November 2015

Ochendowski E., Prawo mieszkaniowe i polityka mieszkaniowa [Housing Law and Housing Policy], Torun 1980

Osт D., The Defeat of Solidarity: Anger and Politics in Postcommunist Europe, Cornell 2006

Pietrzy коwski K., Spółdzielnie mieszkaniowe. Komentarz ${ }^{7}$ [Housing Cooperatives: A Commentary], Warszawa 2013

Pietrzy Kowski K., Spółdzielnie mieszkaniowe. Komentarz ${ }^{5}$, Warszawa 2010

RenNer, K. The Institutions of Private Law and Their Social Functions, translated by A. SCHWARzSCHILD, London 1976 [1904].

Skotarczak T., ŚPIewak-Szyjka M., Spółdzielnie mieszkaniowe w nowym otoczeniu społeczno-gospodarczym, [in:] Spółdzielnie mieszkaniowe: Dylematy funkcjonowania i rozwoju, ed. T. SкотARCzAK, Warszawa 2015

Sкотавсzaк T., Nowe funkcje spółdzielni mieszkaniowych, [in:] Spółdzielnie mieszkaniowe: Dylematy funkcjonowania i rozwoju, ed. T. SкотавсzAк, Warszawa 2015

VAn Der Merwe C., Apartment Ownership, Leiden 1994

Wasilkowski J., Prawo własności w PRL. Zarys wykładu [Right of Ownership in the Polish People's Republic: Outline of a Lecture], Warszawa 1969

Weber M., Economy and Society: An Outline of Interpretive Sociology, Berkeley-Los Angeles 1978

Zweigert K., Kötz H. Introduction to Comparative Law, I: The Framework ${ }^{2}$, Oxford 1987 